\title{
PEMERIKSAAN MATA ANAK SD GULON 2 KECAMATAN SALAM UNTUK MENDUKUNG TUMBUH KEMBANG ANAK
}

\author{
Edward Kurnia Setiawan Limijadi' ${ }^{1)}$, Meita Hendrianingtyas ${ }^{2)}$, Maharani ${ }^{3)}$, \\ Buwono Puruhito ${ }^{4}$, Riski Prihatningtias ${ }^{5}$ \\ ${ }^{1,2)}$ Bagian Patologi Klinik Fakultas Kedokteran Universitas Diponegoro Semarang \\ ${ }^{3,5)}$ Bagian Ilmu Penyakit Mata Fakultas Kedokteran Universitas Diponegoro Semarang \\ ${ }^{4)}$ Bagian Fisiologi Fakultas Kedokteran Universitas Diponegoro Semarang \\ Email: riskiprihatningtias@gmail.com
}

\begin{abstract}
ABSTRAK
Anak usia sekolah perlu mendapatkan perhatian dalam kesehatan tubuhnya untuk dapat menunjang proses tumbuh kembang yang optimal. Salah satu organ yang penting dalam menunjang proses tumbuh kembang adalah mata. Pemeriksaan kesehatan mata diperlukan untuk menapis dan mendiagnosis penyakit mata secara dini. Anak-anak SDN Gulon 2 mayoritas mempunyai orang tua yang bekerja sebagai petani dan memiliki tingkat pengetahuan tentang kesehatan yang rendah. Anak-anak SDN Gulon 2 tersebut belum pernah mendapatkan pemeriksaan kesehatan mata sebelumnya. Tujuan kegiatan pengabdian masyarakat ini adalah penemuan kasus penyakit mata pada anak SDN Gulon 2 dan pemberian edukasi kepada guru SD mengenai penyakit mata yang ditemukan serta pemeberian saran untuk penatalaksanaan penyakit yang ditemukan. Pemeriksaan kesehatan mata yang dilakukan meliputi pemeriksaan visus atau tajam penglihatan dengan Optotype Snellen, pemeriksaan segmen anterior mata dengan loop dan senter, serta pemeriksaan segmen posterior mata dengan oftalmoskop. Edukasi kepada guru dilakukan setelah pemeriksaan selesai dilakukan dan didapatkan suatu diagnosis penyakit mata. Hasil kegiatan pengabdian masyarakat ini berhasil menemukan kelainan tajam penglihatan sebanyak 19 kasus, kelainan segmen anterior 1 kasus dan 1 kasus kelainan segmen posterior. Kegiatan pengabdian masyarakat seperti ini perlu dilakukan di sekolah-sekolah lain di Desa Gulon, dan tidak hanya pemeriksaan kesehatan mata namun kesehatan tubuh secara menyeluruh.
\end{abstract}

Kata kunci: Pemeriksaan Mata, Anak SD, Tumbuh Kembang Anak

\section{ABSTRACT}

School-age children need attention in their physical health to be able to support optimal growth and development processes. One of the organs that is important in supporting the process of growth and development is the eye. An eye health examination is needed to screen and diagnose eye disease early. The majority of SDN Gulon 2 children have parents who work as farmers and have a low level of knowledge about health. The children of SDN Gulon 2 have never received an eye health examination before. The purpose of this community service activity is the discovery of cases of eye disease in SDN Gulon 2 children and the provision of education to elementary school teachers about eye diseases that are found as well as providing suggestions for the management of found diseases. Examination of eye health that was carried out included examination of vision or sharp eyesight with Optotype Snellen, examination of the anterior segment of the eye with a loop and flashlight, as well as examination of the posterior segment of the eye with an ophthalmoscope. Education to teachers is carried out after the examination is completed and an eye disease diagnosis is obtained. Results this community service activity succeeded in finding sharp visual impairment in 19 cases, 1 case anterior segment abnormalities and 1 case posterior segment abnormalities. Community service activities such as this need to be carried out in other schools in Gulon Village, and not only eye health checks but overall body health.

Keywords: Eye Examination, Elementary School Children, Child Growth and Development 


\section{PENDAHULUAN}

Usia sekolah merupakan periode pertumbuhan dan perkembangan anak yang perlu mendapatkan perhatian dengan baik. Pada periode ini dapat terjadi hal-hal yang rentan menyebabkan proses pertumbuhan dan perkembangan anak menjadi terganggu. Hal ini disebabkan karena anak mulai banyak melakukan aktivitas di luar rumah yang dapat mengganggu kesehatan tubuhnya. Pengawasan kesehatan dapat dilakukan oleh orang tua dan guru di sekolah. Apabila orang tua tidak mampu dan kurang mengerti masalah kesehatan, guru sebagai orang tua kedua di sekolah perlu untuk memperhatikan anak didiknya sehingga guru dapat mendeteksi gangguan kesehatan pada anak sejak dini. Kemudian guru dapat menyampaikannya kepada orang tua anak tersebut sehingga dapat dilakukan penanganan segera.

Pengawasan kesehatan anak meliputi kesehatan berbagai organ tubuh dengan kelainannya masing-masing. Hal ini tidak mudah dilakukan bagi seorang guru maupun orang tua murid yang tinggal di pedesaan. Pada masyarakat pedesaan gangguan kesehatan yang masih ringan sering dianggap hal yang biasa dan sering diabaikan sehingga mereka baru datang ke fasilitas kesehatan apabila keadaan sudah sangat parah. Oleh karena itu perlu dilakukan suatu penapisan gangguan kesehatan pada anak sekolah secara dini.

Pemeriksaan kesehatan anak salah satunya pemeriksaan kesehatan mata yang merupakan organ vital bagi manusia berguna untuk melihat. Mata merupakan organ yang tidak dipungkiri harus dipelihara dengan baik demi kelancaran dalam aktivitas seharihari. Dalam proses tumbuh kembang, mata berperan dalam mengenal, mengidentifikasi sesuatu bahkan membaca yang diperlukan bagi seorang anak yang nantinya berkembang menjadi manusia dewasa. Hal inilah yang menjadi penting bagi organ mata karena mnyumbangkan pertumbuhan dan perkembangan seorang anak.

\section{TINJAUAN PUSTAKA}

Tumbuh kembang mata berlangsung sangat cepat sejak bayi dan awal masa kanak-kanak dan mencapai seperti orang dewasa pada usia 12 tahun. Mata pada bayi baru lahir bersifat hiperopik dan bertambah hiperopik sampai usia 7 tahun kemudian mengalami miopisasi serta memiliki ukuran bola mata dewasa pada usia 16 tahun. Selama periode ini dapat terjadi kelainan refraksi. Bila terjadi miopia lebih muda dari 10 tahun, akan berpotensi terjadinya miopia yang progresif sampai mencapai 6 dioptri (American Academic of Ophthalmology, 2014). Oleh karena itu pemeriksaan mata harus dilakukan sejak dini agar kelainan yang terjadi dapat segera diketahui dan mendapatkan penanganan secepatnya sehingga prognosis untuk tajam penglihatan akan lebih baik. Penyebab gangguan penglihatan terbanyak di seluruh dunia adalah kelainan refraksi yang tidak terkoreksi, katarak dan glaukoma. Sebesar 18\% tidak dapat ditentukan dan 1\% adalah gangguan penglihatan sejak masa kanak-kanak. (WHO, 2012). Kelainan refraksi yang tidak terkoreksi merupakan penyebab utama low vision di dunia dan dapat menyebabkan kebutaan. (Kemenkes 2014). Penyakit mata pada beberapa penelitian dapat terjadi pada anak usia SD. Penelitian di Arab Saudi yang mengikutsertakan 1319 anak mendapatkan sebanyak 60 anak menunjukkan berbagai kelainan mata seperti miopia, hiperopia, astigmatisme, ambliopia, strabismus dengan prevalensi yang berbeda-beda (Al-Rowaily, 2010).

Riskesdas (2013) mendapatkan data mengenai kesehatan indera penglihatan dari responden berjumlah 924.780 orang berusia 6 tahun ke atas. Hasil Riskesdas menunjukkan prevalensi kebutaan cenderung lebih rendah dibandingkan prevalensi kebutaan tahun 2007. Prevalensi kebutaan tertinggi ditemukan di Gorontalo $(1,1 \%)$ 
selanjutnya diperoleh prevalensi kebutaan di Nusa Tenggara Timur sebesar 1,0\%, Sulawesi Selatan dan Bangka Belitung masing-masing sebesar 0,8\%. Pusat Data dan Informasi Kementerian Kesehatan RI (2014) menuliskan bahwa Jawa Tengah memiliki prevalensi kebutaan 0,5\% yang setara dengan 149.740 dalam 29.948.036 jumlah penduduk pada usia 5 tahun, sedangkan kejadian severe low vision sebesar 1,1 \% yang setara dengan 329.428 dalam 29.948.036 jumlah penduduk pada usia 5 tahun. Penelitian lain ditemukan prevalensi kelainan refraksi mata sebesar 2,32\% ada anak usia 6-11 tahun di Kecamatan Turi yang dideteksi dengan temuan gejala dan tanda (Fauzi et al., 2016). Angka yang cukup tinggi pada anak usia 6 tahun ke atas ini perlu ditekan kembali. Untuk itu perlu dilakukan upaya pemeriksaan kelainan refraksi mata pada anak anak sekolah dasar sehingga dapat segera dilakukan koreksi dan diterapi sedini mungkin selain itu perlu diketahui tingkat kelainan refraksi mata pada anak anak sekolah dasar.

Desa Gulon terletak di kecamatan Salam yang sebenarnya tidak jauh dari Kota Muntilan. Letak desa ini juga dekat dengan Kota Magelang yang akses kesehatan dapat terjangkau dengan angkutan umum. Walaupun demikian, keadaan letak kedua kota tersebut dianggap cukup jauh oleh warga desa Gulon. Mata pencaharian warga desa sebagai besar adalah petani yang berpendidikan rendah. Pendidikan yang rendah membuat warga desa memiliki pengetahuan kesehatan dalam hal pencegahan dan penemuan kasus penyakit yang rendah. Anak-anak SD memang sebelumnya belum pernah dilakukan pemeriksaan kesehatan mata, dan keluhan penglihatan kurang dianggap biasa oleh orang tua maupun guru mereka.

Keadaan tersebut yang menjadikan latar belakang peneliti melakukan kegiatan pengabdian pemeriksaan kesehatan mata anak SDN Gulon 2 berjalan. Anak-anak SD perlu mendapatkan pemeriksaan mata dini yang bertujuan untuk menapis dan mendiagnosis secara dini penyakit mata pada anak-anak SD. Edukasi kepada guru sebagai orang tua kedua anak SD perlu dilakukan untuk memberikan gambaran penyakit mata sehingga anak SD dapat tumbuh kembang secara optimal dengan penanganan yang memadai.

\section{METODE PELAKSANAAN}

Langkah awal yang dilakukan adalah mencari tempat untuk pengabdian yaitu di SDN Gulon 2 Desa Gulon Kecamatan Salam, Kabupaten Magelang yang memang belum pernah dilakukan pemeriksaan kesehatan mata. Kegiatan pemeriksaan mata terdiri dari pemeriksaan visus menggunakan optotype Snellen untuk menilai ketajaman penglihatan. Pemeriksaan ini dilakukan dengan pembacaan huruf-huruf pada alat periksa dengan interpretasi hasil ketajaman penglihatan antara 6/60 sampai dengan 6/6. Apabila anak tidak dapat melihat alat periksa tersebut maka dilakukan pemeriksaan ketajaman penglihatan dengan hitung jari dengan interpretasi 1/60 sampai dengan 6/60. Pemeriksaan mata dengan lambaian tangan dilakukan apabila hitung jari tidak dapat dilakukan, dan memiliki interpretasi hasil pemeriksaan yaitu 1/300. Cara terakhir yaitu dengan persepsi cahaya yang dilakukan menggunakan lampu senter yang memiliki interpretasi $1 /$ tak terhingga apabila dapat melihat cahaya tersebut, 0 atau tidak ada cahaya jika tidak dapat melihat cahaya yang dipancarkan dari senter.

Pemeriksaan kesehatan mata selanjutnya yaitu pemeriksaan segmen anterior atau bagian depan bola mata, yang dinilai mulai dari palpebra sampai dengan lensa bagian depan menggunakan loop dan senter. Pemeriksaan terakhir yaitu pemeriksaan segmen posterior atau bagian belakang bola mata, yang digunakan untuk menilai keadaan retina dan saraf mata, denagn menggunakan oftalmoskop. 
Hasil pemeriksaan dicatat untuk setiap anak dan dilakukan analisis hasil pemeriksaan kesehatan mata tersebut. Indikator keberhasilan dari kegiatan ini yaitu penemuan kasus penyakit mata pada anak SD.

\section{HASIL DAN PEMBAHASAN}

Pemeriksaan kesehatan mata dilakukan pada 38 anak SD Gulon 2. Sebelum pemeriksaan dimulai, anak-anak diberi pengarahan dahulu yang dibantu oleh para guru SD. Pengarahan yang dilakukan yaitu pemberitahuan pemeriksaan yang dilakukan ada tiga macam. Saat pemeriksaan membaca huruf yang ditunjuk oleh pemeriksa, anak-anak menutup mata bergantian tanpa penekanan pada mata yang ditutup, dan anak-anak lain tidak ikut bersuara untuk memberitahukan huruf apa yang ditunjuk. Setelah pengarahan, anak-anak satu persatu mulai diperiksa secara bergantian meliputi pemeriksaan visus, segmen anterior dan segmen posterior mata. Hasil pemeriksaan dicatat di dalam lembar tabel yang telah disiapkan meliputi nama, usia, jenis kelamin, visus, status segmen anterior, dan status segmen posterior. Hasil pemeriksaan didapatkan data sebagai berikut tabel 1 .

Pemeriksaan kesehatan mata ini dilakukan pada anak-anak SD kelas 4,5, dan 6 dengan pertimbangan anak sudah mahir membaca dan dapat diajak bekerja sama saat dilakukan pemeriksaan. Usia anak-anak yang diperiksa dari umur 9 sampai 12 tahun. Jumlah anak perempuan lebih banyak dari anak laki-laki.

Tabel 1. Data Karakteristik dan Hasil Pemeriksaan Mata Anak SDN Gulon 2

\begin{tabular}{|c|c|c|c|c|}
\hline Parameter & \multicolumn{2}{|c|}{ Jumlah Anak } & \multicolumn{2}{|c|}{ Persentase } \\
\hline \multicolumn{5}{|l|}{ Usia } \\
\hline - 9 tahun & \multicolumn{2}{|c|}{10} & \multicolumn{2}{|c|}{$26.31 \%$} \\
\hline - 10 tahun & \multicolumn{2}{|c|}{8} & \multicolumn{2}{|c|}{$21.05 \%$} \\
\hline - $\quad 11$ tahun & \multicolumn{2}{|c|}{10} & \multicolumn{2}{|c|}{$26.31 \%$} \\
\hline$-\quad 12$ tahun & \multicolumn{2}{|c|}{10} & \multicolumn{2}{|c|}{$26.31 \%$} \\
\hline \multicolumn{5}{|l|}{ Jenis kelamin } \\
\hline - Laki-laki & \multicolumn{2}{|c|}{15} & \multicolumn{2}{|c|}{$39.47 \%$} \\
\hline - Perempuan & \multicolumn{2}{|c|}{23} & \multicolumn{2}{|c|}{$60.54 \%$} \\
\hline Visus & OD & OS & OD & OS \\
\hline - $\quad$ Normal $(6 / 6)$ & 22 & 22 & $57.89 \%$ & $57.89 \%$ \\
\hline - Gangguan visus ringan $(<6 / 12)$ & 13 & 12 & $34.21 \%$ & $31.57 \%$ \\
\hline - $\quad$ Gangguan visus sedang $(<6 / 18)$ & 2 & 4 & $5.26 \%$ & $10.53 \%$ \\
\hline - $\quad$ Gangguan visus berat $(<6 / 60)$ & - & - & - & - \\
\hline - $\quad$ Buta $(<3 / 60)$ & 1 & - & $2.63 \%$ & - \\
\hline Segmen anterior & OD & OS & OD & OS \\
\hline - Normal & 37 & 37 & $97.36 \%$ & $97.36 \%$ \\
\hline - Tidak normal & 1 & 1 & $2.63 \%$ & $2.63 \%$ \\
\hline Segmen posterior & OD & OS & OD & OS \\
\hline - Normal & 37 & 37 & $97.36 \%$ & $97.36 \%$ \\
\hline - $\quad$ Tidak normal & 1 & 1 & $2.63 \%$ & $2.63 \%$ \\
\hline
\end{tabular}


Pada pemeriksaan visus didapatkan 57,89\% anak memiliki tajam penglihatan yang masih normal. Gangguan visus dari ringan sampai berat disebabkan karena kelainan refraksi. Hal ini karena anak-anak tersebut mengeluhkan penglihatan yang lebih kabur apabila duduk di barisan belakang dan penglihatan menjadi lebih jelas saat dudu di barisan depan. Namun sayang untuk diagnosis pasti jenis kelainan refraksi tidak dapat diperoleh, pemeriksaan yang dilakukan hanya pemeriksaan visus dasar tanpa koreksi, karena adanya keterbatasan alat. Satu anak memiliki kelainan pada segmen anteriornya berupa injeksi dan papil pada konjungtiva palpebra, dengan diagnosis konjungtivitis vernal. Satu anak memiliki kelainan pada segmen posterior, berupa skar korioretina di makula mata kanan dan kiri, visus anak tersebut juga buruk, visus mata kanan $1 / 60$, visus mata kiri 6/48. Pada mata kanan anak tersebut didapatkan exotropi (juling ke arah luar), dan terdapat nistagmus di kedua mata. Kemungkinan penyebab kondisi anak tersebut adalah infeksi toxoplasma sejak kecil atau saat di dalam kandungan.

Pemeriksaan mata yang telah dianalisis dan dicatat lalu dilaporkan kepada guru SD yang selanjutnya guru diberikan edukasi mengenai penyakit mata yang terjadi pada anak didiknya meliputi definisi, penyebab dan penanganan medis selanjutnya. Anak-anak yang mengalami gangguan kesehatan mata harus dibawa ke fasilitas kesehatan. Keadaan kelainan refraksi yang terjadi dapat dilakukan koreksi dengan membawa anak SD ke rumah sakit dan optic untuk mendapatkan kacamata. Dengan demikian, harapannya anak SD dapat terkoreksi kelainan refraksi matanya dan tidak bertambah progresif.

Hasil penelitian ini menunjukkan $42.11 \%$ siswa kelas 4,5, dan 6 SD Gulon 2 mempunyai gangguan visus dari ringan sampai berat. Satu anak dengan visus $<3 / 60$ atau sudah dikategorikan buta akibat adanya kelainan di segmen posterior. Gangguan visus dari ringan sampai berat diakibatkan karena kemungkinan adanya kelainan refrkasi. Anak-anak mengeluhkan penglihatannya kabur saat duduk di belakang dan penglihatan menjadi jelas setelah duduk di depan. Hal ini sesuai dengan gejala kelaianan refraksi yaitu miopia atau rabun jauh. Miopia terjadi karena cahaya jatuh di depan retina. Menurut Murthy (2000), kelainan refraksi berupa myopia sudah mulai muncul pada kelompok umur 6 - 11 tahun (sekolah dasar) dan terus berkembang serta menetap pada kelompok umur $>12$ tahun (sekolah lanjutan) (Fauzi et al, 2016).

Menurut WHO (2012), anak-anak yang berusia di bawah 15 tahun diperkirakan sebanyak 19 juta mengalami gangguan penglihatan dan 12 juta di antaranya disebabkan oleh kelainan refraksi mata, suatu kondisi yang seharusnya mudah untuk didiagnosis dan diperbaiki. Kejadian miopia yang terus meningkat dalam 50 tahun terakhir diperkirakan sudah mengenai 1,6 miliar penduduk di seluruh dunia. Institute of Eye Research memperkirakan pada tahun 2020 jumlah penderita miopia akan mencapai 2,5 miliar penduduk. WHO telah menetapkan miopia sebagai salah satu prioritas utama untuk mengendalikan dan mencegah kebutaan didunia pada tahun 2020 karena miopia menjadi salah satu penyebabnya. Data WHO menunjukkan bahwa $10 \%$ dari 66 juta anak usia sekolah menderita miopia. Prevalensi miopia pada tahun 2002 sebesar 70-90\% di beberapa negara di Asia, 30-40\% di Eropa dan Amerika Serikat, serta 10-20\% di Afrika.

Prevalensi miopia juga ditemukan meningkat pada anak-anak seiring dengan pertambahan umur. Prevalensi miopia pada anak-anak di Amerika adalah sebesar 3\% pada usia 5-7 tahun, $8 \%$ pada usia $8-10$ tahun, $14 \%$ pada usia $11-12$ tahun, dan $25 \%$ pada usia 12-17 tahun. Penelitian di Taiwan menemukan prevalensi miopia sebesar $12 \%$ pada 
anak-anak usia 6 tahun dan 84\% pada usia 16-18 tahun, kemudian data di Jepang juga mendapatkan peningkatan prevalensi miopia seiring dengan pertambahan umur yaitu ditemukan sebesar 43,5\% pada anak usia 12 tahun dan meningkat menjadi 66\% pada anak usia 17 tahun. Indonesia menempati urutan pertama pada prevalensi kelainan refraksi penyakit mata dengan ditemukan jumlah penduduk yang menderita kelainan refraksi hampir 25\% populasi penduduk atau sekitar 55 juta jiwa. Angka kelainan refraksi di Indonesia mencapai $22,1 \%$ yang diantaranya dialami oleh anak usia sekolah sebanyak $10 \%$. Prevalensi miopia di Indonesia berdasarkan penelitian yang di lakukan di Sumatera pada tahun 2002 adalah sebesar 26,1\%. Prevalensi kelainan refraksi yang dilakukan di salah satu SD di Jakarta didapatkan angka yang cukup tinggi yaitu 51.46\%. (Mokoginta et al, 2017).

Oleh karena itu, diperlukan adanya deteksi dini kelainan refraksi mata pada usia sekolah agar dapat ditemukan kasus kelainan refraksi secara dini. Kelainan refraksi yang tidak ditangani secara baik akan menyebabkan ambliopia atau mata malas. Ambliopia akan menyebabkan penglihatan mata anak menjadi tidak optimal walaupun sudah memakai kacamata.

Konjungtivitis vernal merupakan salah satu bentuk radang pada konjungtiva yang disebabkan oleh reaksi hipersensitivitas. Predisposisi penyakit ini adalah anak-anak usia sekolah dasar dan jenis kelamin laki-laki. Gejala penyakit ini adalah mata merah dan gatal. Penyakit ini sering kambuh yang biasanya terjadi saat musim panas dan akan menghilang saat masa pubertas. Penyakit ini tidak berbahaya, namun karena sering kambuh akan mengganggu aktivitas anak tersebut. Penanganan konjungtivitis vernal meliputi terapi fase akut dengan pemberian kortikosteroid topikal, dan pemberian tetes mata mast cell stabilizer untuk mencegah kekambuhan. Edukasi untuk menghindari paparan panas matahari dan debu juga dianjurkan untuk mencegah bertambah parahnya gejala. (Kraus CL, 2016) (Lionardi, 2013)

Manifestasi okuler pada infeksi intrauterine sangat beragam, namun skar chorioretina dan atau chorioretinitis aktif merupakan manifestasi klinis yang paling sering dilaporkan. Skar chorioretina dalam persentase kasus yang tinggi disebabkan karena infeksi bawaan Toxoplasma gondii, virus Herpes simplex, virus limfositikus koriomeningitis dan West-Nile virus. (Tomi et al, 2016). Toxoplasmosis pada mata dapat terjadi secara congenital dan didapat. Jika ibu tertular infeksi Toxoplasma selama atau segera sebelum kehamilan, ada risiko signifikan terjadinya transmisi lewat plasenta, dan risikonya meningkat seiring bertambahnya usia kehamilan. Dunn et al. melaporkan keseluruhan tingkat transmisi vertical sebesar 29\%. Risiko penularan di awal kehamilan rendah, $6 \%$ pada usia kehamilan 13 minggu, dan meningkat pesat pada trimester kedua dan ketiga, mencapai $72 \%$ pada 36 minggu. Meskipun tingkat transmisi rendah, keparahan dan morbiditas toxoplasmosis jauh lebih tinggi pada bayi yang terinfeksi periode awal kehamilan. (Ozgonul et al, 2017). Manifestasi klinis akibat infeksi Toxoplasma intrauterine meliputi skar chorioretina, microkornea, katarak, atrofi optik, microphthalmia, retinitis, retinal detachment, vitritis, strabismus, nistagmus, dan ptisis. (Mets et al, 2008). Skar korioretina ini paling sering berada di makula sehingga menyebabkan prognosis visus yang buruk.

\section{KESIMPULAN}

Pengetahuan guru SDN Gulon 2 mengenai kesehatan mata maupun penyakit mata anak didiknya masih kurang. Penyuluhan kepada guru SD telah dilakukan sebagai upaya untuk deteksi dini kelainan mata pada anak didiknya dan tindakan penanganan berikutnya telah diberitahukan kepada guru agar anak mendapatkan penanganan yang komprehensif. 
Kegiatan penyuluhan ini mencapai indikator keberhasilan yaitu penemuan kasus penyakit mata pada anak SDN Gulon 2 dengan pemeriksaan kesehatan mata yang sebelumnya belum pernah dilakukan. Perlu dilakukan pemeriksaan kesehatan mata anak SD di desa Gulon maupun kesehatan organ tubuh lain agar kasus-kasus penyakit dapat segera terdiagnosis untuk menunjang tumbuh kembang yang optimal.

\section{DAFTAR PUSTAKA}

[1]. Al-Rowaily MA. Prevalence of Refractive Errors Among Pre-school Children at King Abdulaziz Medical City, Riyadh, Saudi Arabia. Saudi Journal of Ophthalmology. 2010 (24): 45-48

[2]. Badan Penelitian dan Pengembangan Kesehatan. Kementrian Kesehatan RI, 2013. Riset Kesehatan Dasar 2013.

[3]. Fauzi L, Anggorowati L, Heriana C, 2016. Skrining Kelainan Refraksi Mata Pada Siswa Sekolah Dasar Menurut Tanda dan Gejala. Journal of Health Education. 1(1): 79-84

[4]. Kraus CL, 2016. Vernal conjunctivitis. American Academy of Ophthalmology. Available from : https://www.aao.org/disease-review/vernal-keratoconjunctivitis5

[5]. Leonardi A, 2013. Management of Vernal Keratoconjunctivitis. Ophthalmol Ther. 2: 73-88

[6]. Mets MB, Chhabra MS, 2008. Eye Manifestations of Intrauterine and Their Impact on Childhood Blindness. Survey of Ophthalmology. 53(2) : 95-111

[7]. Mokoginta SN, Marsiati H, Indriawati A, Susmiarsih TP, 2017. Prevalensi Kelainan Refraksi pada Siswa SD Negeri 09 Pagi Tanah Tinggi Jakarta Pusat. Majalah Sainstekes, 4(1): 30-35

[8]. Ozgonul C, Besirli CG, 2017. Recent Developments in The Diagnosis and Treatment of Ocular Toxoplasmosis. Ophthalmic Res. $57: 1-12$

[9]. Park YH, Nam HW, 2013. Clinical features and treatment of ocular toxoplasmosis. Korean Journal of Parasitology. 51(4): 393-399.

[10]. Pusat Data dan Informasi Kementrian Kesehatan RI, 2014. Situasi Gangguan Penglihatan dan Kebutaan. Dalam rangka peringatan "Hari Penglihatan Sedunia", 9 Oktober 2014.

[11]. Tomi A, Stefan I, 2016. Bilateral Chorioretinal Scars in A Child - Case Report. Medica- A Journal of Clinical Medicine. 11(2): 163-166

[12]. Turbert D, 2014. Normal Vision Development in Children. American Academy of Ophthalmology. Available from: https://www.aao.org/eye-health/tipsprevention/children-vision-development

[13]. World Health Organization, 2012. Global Data on Visual Impairment 2010 